\title{
Aplikasi Teknologi Fermentasi Jerami Padi Sebagai Sumber Pakan Alternatif Ternak Sapi Bali Untuk Mengatasi Kekurangan Pakan Di Kelompok Tani Nek’to Noapala Desa Kiuola Kecamatan NoemutiKabupaten TTU
}

\author{
Oktovianus R. Nahak, Hilarius Y. Sikone, Maria Magdalena Kolo \\ Program Studi Peternakan, Fakultas Pertanian, Universitas Timor-Kefamenanu, NTT \\ Pos-el : mariamagdalenachem89@gmail.com \\ Koresponding email :mariamagdalenachem89@gmail.com
}

\begin{tabular}{|l|l|l|}
\hline Dikirim: 1 Februari 2019 & Direvisi: 20 Februari 2019 & Diterbitkan: hh, bb, tt \\
\hline
\end{tabular}

\begin{abstract}
Abstrak
Kelompok Tani Nek'To Noapala terletak di Desa Kiuola Kecamatan Noemuti Kabupaten Timor Tengah Utara. Desa ini memiliki beberapa potensi pertanian dan peternakan yang dapat dikembangkan oleh petani, salah satunya tanaman padi (Oriza sativa L.) dan hasil ikutan dari tanaman padi tersebut dimanfaatkan untuk produktivitas ternak sapi. Jerami padi merupakan limbah dari tanaman padi sebagai pakan ternak memiliki kadar protein rendah, berserat tinggi dan berdaya cerna rendah sehingga diperlukan adanya suatu perlakuan yaitu dengan teknologi fermentasi. Metode yang dipakai dalam kegiatan pengabdian ini berupa FGD( Foccus Discussion Group) dan praktek secara langsung. Proses fermentasi dilakukan dengan dua tahap yaitu tahap fermentasi dan pengeringan. Proses fermentasi berlangsung selama 21 hari secara anaerob. Hasil yang diperoleh yaitu jerami padi hasil fermentasi yang memiliki kualitas fisik cukup baik diantaranya memiliki tekstur yang lembut, warna kuning kecoklatan dan aroma seperti tapeserta hasilnya langsung diaplikasikan ke ternak sapi. Disimpulkan bahwa kegiatan pengabdian ini dapat meningkatkan pengetahuan dan keterampilan masyarakat terkhususnya anggota kelompok tani Nek'To Noapala Desa Kiuola tentang pemanfaatan jerami padi secara fermentasi sebagai pakan alternatif bagi ternak sapi.

Kata Kunci : Alternative Pakan, Fermentasi, Jerami Padi

\section{Abstract}

The Nek'To Noapala Farmers Group is located in the Kiuola Village of Noemuti District, Timor Tengah Utara Regency. This village has several agricultural and livestock potentials that can be developed by farmers, one of which is rice (Oriza sativa L.) and the by-products of rice plants are used for the productivity of cattle. Rice straw is a waste from rice plants as animal feed has a low protein content, high fibrous and low digestibility so it is necessary to have a treatment that is by fermentation technology. The method used in this service activity is in the form of Foccus Discussion Group and direct practice. The fermentation process is carried out in two stages, namely the fermentation and drying stages. The fermentation process lasts for 21 days anaerobically. The results obtained are fermented rice straw which has good physical quality including soft texture, brownish yellow and aroma like tape and the results are immediately applied to cattle. It was concluded that this service activity could improve the knowledge and skills of the community especially members of the Nek'To Noapala farmer group in Kiuola Village about the utilization of fermented rice straw as an alternative feed for cattle.
\end{abstract}

Keywords: Alternative Feed, Fermentation, Rice Straw

\section{PENDAHULUAN}


Ketersediaan pakan baik dari segi kuantitas, kualitas dan secara berkesinambungan sepanjang ttahun perlu diperhatikan karena disisi lain saat musim kemarau, banyak peternak local yang mengeluhkan sussahnya mencari hijauan pakan ternak akibat sebagian besar rumput, terutama rumput lapangan sudah mongering dan meranggas. Alangkah baiknya pada saat panen raya padi, limbah padi yang berupa jerami dapt dimanfaatkan sebagai cadangan pakan menginjak musim kemarau. Pemanfaatan jerami padi dapat dijadikan salah satu jalan keluar, karena jerami padi yang melimpah dapat dimanfaatkan sebagai pakan ternak (Martawidjaja.,2003).

Jerami padi segar yang dihasilkan dari satu hektar sawah bervariasi Antara 12-15 ton/musim panen atau berkisar 4-5 ton/ha/kering. Namun kandungan lignin dalam jerami yang merupakan ikatan lignoselulosa menyebabkan jerami sulit diuraikan oleh ternak. Akibatnya jerami dapat dicerna ternak hanya 35\%, sehingga kandungan nutrisi yang ada dalam jerami tidak dapat dimanfaatkan secara optimal. Salah satu upaya yang dapat dilakukan untuk meningkatkan kecernaan dan gizi jerami adalah dengan cara fermentasi dengan menggunakan bekteri anaeorob. Hasil fermentasi menunjukkan bahwa nilai kecernaan jerami meningkat, atau daya cerna sapi menjadi lebih meningkat. Selanjutnya protein tersebut akan cepat terdegradasi dan dirombak menjadi $\mathrm{NH}_{3}$ yang dapat dimanfaatkan oleh bakteri untuk memperbanyak dirinya (Amin et all., 2015).

Adapun Kelompok Tani Nek'To Noapala terletak di Desa Kiuola Kecamatan Noemuti Kabupaten Timor Tengah Utara. Desa ini memiliki beberapa potensi pertanian dan peternakan yang dapat dikembangkan oleh petani, salah satunya tanaman padi (Oryza Sativa L.) dan hasil ikutan dari tanaman padi tersebut yang dapat dimanfaatkan untuk produktivitas ternak sapi.

Secara umum kecamatan Noemuti memiliki lahan sawah seluas 11,401 ha dan memproduksi jerami sebanyak 26,197 ton pada tahun 2013 (BPS, 2014). Orientasi para petani khususnya pada usaha pertanianpadi sawah di Desa Kiuola, lebih dititikberatkan pada usaha pemenuhan kebutuhan langsung dari keluarga atau subsistence production oriented. Selain orientasi yang dikemukakan diatas, rendahnya tingkat pendidikan petani sawah menjadi penyebab rendahnya kemampuan berusaha yang beorientasi komersial. Selain itu juga, sistem pertanian/peternakan di kelompok tani Nek'To Noapala masih berpindah-pindah dan tidak konsentrasi pada salah satu hasil pertanian. Di Desa ini pada umumnya sama dengan kondisi daerah lain dimana pakan menjadi salah satu penyebab utama menurunnya produktivitas ternak khususnya ternak sapi. Padahal ketersediaan jerami yang merupakan limbah pertanian dapat dimanfaatkan sebagai pakan alternatif dalam mengatasi kekurangan pakan tersebut. Dengan adanya kegiatan pengabdian pada masyarakat ini diharapkan masyarakat dapat memanfaatkan jerami padi oleh petani di Desa Kiuola.

\section{METODE}

Kegiatan pengabdian berlangsung di kelompok Nek'To Desa Kiuola Kecamatan Noemuti Kabupaten TTU pada bulan Juli-Agustus 2018. Metode yang digunakan dalam kegiatan pengabdian ini adalah FGD (focus discussion group) sekaligus praktek secara langsung tentang pembuatan fermentasi jerami padi dan akan terus didampingi oleh tim pengabdian sampai kelompok tani terampil, mahir dan mandiri dalam mengaplikasikan teknologi 
fermentasi pakan ternak berbasis limbah pertanian. Proses fermentasi dilakukan dengan 2 tahap yaitu tahap fermentasi dan pengeringan.

Tahap pertama

- Jerami padi yang baru dipanen dicacah menjadi potongan yang lebih kecil

- Kemudian ditumpuk secara merata pada tempat yang telah disediakan dengan ketinggian $20 \mathrm{~cm}$ sebagai lapisan 1

- Sementara itu, larutan gula dicampurkan dengan larutan EM4 dan ditambahkan dengan air secukupnya.

- Lapisan 1 jerami padi kemudian di taburi dengan dedak padi secara merata ke seluruh permukaan jerami padi

- Penyiraman secara merata campuran larutan gula dan EM4 ke seluruh permukaan jerami padi

- Kemudian ditambahkan lagi timbunan jerami padi setebal $20 \mathrm{~cm}$ lalu taburi lagi dedak padi, lalu larutan gula dan EM4 secara merata seperti sebelumnya. demikian seterusnya sampai tumbukan jerami padi mencapai 1-2 m

- Tumpukan tersebut kemudian ditutp dengan terpal

- Kemudian didiamkan selama 21 hari, agar proses fermentasi berlangsung secara sempurna.

Tahap kedua:

- Tumpukan jerami padi yang telah mengalami proses fermentasi, dikering-anginkan hingga cukup kering sebelum disimpan pada tempat terlindung dari hujan dan sinar matahari langsung

- Setelah kering jerami fermentasi dapat diberikan kepada sapi sebagai pakan pengganti rumput segar

\section{HASIL DAN PEMBAHASAN}

\section{Bahan Pembuatan Fermentasi Jerami Padi}

Fermentasi jerami padi merupakan serangkaian proses yang dilakukan untuk menambah kandungan nutrisi jerami padi dan kecernaannya sehingga lebih efisien dikonsumsi oleh ternak ruminansia (sapi potong).

Proses pembuatan teknologi fermentasi jerami padi telah dilakukan dengan menggunakan bahan-bahan yang sederhana dan mudah diperoleh diantaranya:

1. Jerami padi. Jerami padi ketersediaannya melimpah di desa Kiuola karena wilayah desa Kiuola memiliki hamparan sawah yang cukup luas. Komposisi kimia jerami padi ditandai oleh rendahnya kadar nitrogen dan mineral esensial, sedangkan kadar serat kasarnya tinggi sehingga kecernaannya mencapai 37\%. Jerami padi mengandung 21\% inti dan $79 \%$ diding sel berdasarkan berat kering. Dari $79 \%$ berat kering ini mengandung 26\% hemiselulosa, $33 \%$ selulosa, $7 \%$ lignin, dan silica $13 \%$ (Ilham et all ., 2018). 
2. Dedak padi merupakan hasil samping dari penggilingan padi yang mengandung BK $89,6 \%$, PK 15,9\%, SK 8,5\%. Dedak padi dipakai sebagai bahan tambahan karena memiliki nilai gizi yang tinggi.

3. Gula. Pada proses fermentasi ini digunakan gula dari pohon nira yang bermanfaat sebagai pemanis pakan serta sebagai makanan mikroorganisme pengurai karena memiliki kandungan sukrosa yang cukup tinggi

4. EM4. Kandungan EM4 terdiri dari bakteri fotosintetik, bakteri asam laktat, actinomicetes, ragi dan jamur fermentasi. Bakteri fotosintetik membentuk zat-zat bermanfaat yang menghasilkan asam amino, asam nukleat dan zat-zat bioaktif yang berasal dari gas berbahaya dan berfungsi untuk mengikat nitrogen dari udara. Bakteri asam laktat berfungsi untuk fermentasi bahan organik jadi asam laktat, percepat perombakan bahan organik, lignin dan cellulose, dan menekan pathogen dengan asam laktat yang dihasilkan. Actinomicetes menghasilkan zat anti mikroba dari asam amino yang dihasilkan bakteri fotosintetik.

5. Air.Air yang digunakan berfungsi untuk memperbanyak volume dan melarutkan EM4 bersama gula sehingga lebih mudah dipercik ke jerami padi yang akan difermentasi.

\section{Proses Pembuatan Dan Fermentasi}

Proses pembuatan teknologi fermentasi jerami ini dimulai dengan penyediaan semua bahan campuran fermentasi. Jerami padi hasil pertanian dikeringkan kemudian dicacah menjadi bagian kecil agar menjadi bentuk dengan ukuran yang homogeny sehinngga proses pencampuran bahan tambahan fermentasi lainnya dapat merata sampai ke seluruh permukaan jerami. jerami hasil cacahan di tumpuk pada terpal secara merata hingga ketinggian $20 \mathrm{~cm}$ dan selannjutnya ditaburi secara merata dengan dedak padi. tahapan selanjutnya yaitu mencampurkan EM4 dengan larutan gula dan air secukupnya. Kemudian campuran larutan tersebut disebarkan atau disiramkan secara merata ke atas permukaan jerami padi yang telah ditumpuk tersebut. proses yang sama dilakukan untuk lapisan selanjutnya sampai lapisan tersebut mencapai ketinggian 2 meter dari permukaaan tanah. Setelah itu tumpukan jerami padi yang telah dicampur dengan merata ditutup dengan terpal sehingga terjadi proses fermentasi. Proses fermentasi ini berlangsung selama 21 hari dalam kondisi anaerob.

Setelah 21 hari proses fermentasi berlangsung, kemudian hasil fermentasi jerami padi di buka untuk melihat kualitas fisik. Hasil kualitas fisik dari fermentasi jerami padi memiliki kualitas yang baik yang ditandai dengan Baunya agak harum, warnanya kuning agak kecoklatan, teksturnya lemas (tidak kaku), tidak busuk dan tidak berjamur.

\section{Kualitas Fisik Fermentasi Jerami}

Berdasarkan hasil pengamatan kualitas fisik fermentasi jerami padi diperoleh :

- Warna. Perubahan warna jerami padi hasil fermentasi dari kuning menjadi warna coklat mengindikasikan bahwa proses fermentasi telah berlangsung. Reksohadiprodjo (1988) menyatakan perubahan warna terjadi pada tanaman yang mengalami proses ensilase yang disebabkan oleh perubahan-perubahan yang terjadi dalam tanaman karena proses 
respirasi anaerobik yang berlangsung selama persediaan oksigen masih ada hingga gula tanaman habis.

- Tekstur. Tekstur fermentasi jerami padi yang lembut atau lemas dan halus disebabkan ikatan lignin, sellulosa, dan silika pada dinding jerami lepas. Semakin lama proses fermentasi maka tekstur jerami padi akan semakin lembut dan lunak sehingga lebih mudah dicerna oleh mikroba rumen. kriteria amoniasi yang baik adalah berwarna kecoklat-coklatan, kering, jerami hasil fermentasi lebih lembut dibandingkan jerami asalnya.

- Bau. Bau yang dihasilkan memberikan aroma harum seperti aroma tape dari proses fermentasi yaitu aroma asam laktat.

\section{Respon Ternak Terhadap Fermentasi Jerami Padi}

Respon ternak terhadap fermentasi jerami padi yang dibuat merupakan hal penting untuk melihat daya tarik atau tingkat kesukaan ternak terhadap pakan. Palatabilitas merupakan salah satu faktor penting untuk melihat konsumsi ternak yang pada umumnya dipengaruhi oleh aroma, rasa, warna serta tekstur pakan. Menurut Kartadisastra (1997), keadaan fisik dan kimiawi pakan yang dicerminkan dari kenampakan, aroma, rasa, dan tekstur dapat menggambarkan daya tarik sehingga dapat merangsang ternak untuk mengkonsumsinya. Dari hasil fermentasi yang dilakukan selama 21 hari jerami padi tersebut memiliki tekstur yang lembut atau lemas dan halus, aroma yang khas seperti tape dan warna kecoklatan. Setelah 21 hari difermentasi kemudian diaplikasikan atau dicobakan ke ternak sapi dari anggota kelompok tani. Pada mulanya ternak sapi belum begitu tertarik dengan jerami padi hasil fermentasi tersebut. Hal ini disebabkan karena ternak sapi tersebut belum terbiasa mengkonsumsi jerami padi dari hasil fermentasi sehingga perlu melewati vase adaptasi. Setelah beberapa saat kemudian nampak bahwa ternak sapi tersebut mulai perlahan- lahan mengkonsumsi jerami padi hasil fermentasi tersebut. Hasil pengamatan menunjukkan bahwa daya terima ternak sapi terhadap jerami padi hasil fermentasi yang diberikan cukup tinggi. Daya terima ternak terhadap jerami padi hasil fermentasi yang cukup tinggi ini menjadi faktor pendorong agar teknologi fermentasi jerami padi ini dapat diterapkan oleh petani/peternak dalam memanfaatkan limbah pertanian sebagai bahan pakan alternative terhadap ternaknya.

\section{Tingkat Pemahaman Anggota Kelompok Tani}

Respon anggota kelompok tani Nek'To Noapala Desa Kiuola cukup baik dilihat dari kehadiran para anggota pada saat kegiatan pengabdian ini. Rasa antusias dibuktikan dengan berbagai pertanyaan yang disampaikan kepada tim pengabdi sebab sebelumnya mereka belum pernah mengetahui tentang teknologi pakan ternak menggunakan jerami padi menggunakan proses fermentasi. Berdasarkan data anggota kelompok yang dikumpulkan, diketahui bahwa jumlah anggota kelompok 21 orang terdiri dari 7 orang perempuan dan 14 orang laki-laki dimana tingkat endidikan mereka rata-rata sekolah dasar. Tingkat pendidikan tersebut mempengaruhi kemampuan pemahaman mengenai pemanfaatan limbah pertanian sebagai alternative pakan ternak. Pada saat demonstrasi pembuatan fermentasi jerami padi, semua anggota kelompok tani ikut ambil bagian dalam memraktekan cara pembuatan 
fermentasi jerami padi. Dari hal ini dapat dilihat bahwa tingkat pemahaman masyarakat terkhususnya kelompok tani Nek'To Noapala semakin meningkat setelah dilakukan kegiatan pengabdian masyarakat ini.

\section{SIMPULAN}

Kegiatan pengabdian aplikasi teknologi Fermentasi Jerami Padi Sebagai Sumber Pakan Alternatif Ternak Sapi Bali telah dilaksanakan dengan baik. Adapun banyak manfaat yang telah didapatkan dari hasil kegiatan pengabdian ini yaitu membantu masyarakat setempat untuk mengatasi kekurangan pakan yang dialami saat ini. Selain itu juga masyarakat memperoleh banyak pengetahuan tentang manfaatan limbah pertanian untuk memenuhi kebutuhan pakan ternak, serta langsung mempraktekan proses pembuatan fermentasi jerami padi dengan menggunakan alat dan banhan yang sederhana. Akhir dari kegiatan ini diharapkan memberi manfaat bagi kelompok tani dalam meningkatkan produktivitas ternak khususnya sapi potong serta adanya kerjasama yang terus berlanjut.

Jerami fermentasi yang diperoleh mempunyai kualitas yang cukup baik yang ditandai dengan aroma khas dan tekstur yang lembut dan langsung dikonsumsi oleh ternak sapi kelompok tani Nek'to Noapala desa Kiuola Kecamatan Noemuti. Kegiatan pengabdian ini telah meningkatkan pengetahuan dan keterampilan anggota kelompok tani dalam mengaplikasikan jerami padi sebagai bahan pakan alternatif.

\section{UCAPAN TERIMA KASIH}

Ucapan terima kasih diberikan bagi LPPM Universitas Timor sebagai penyandang dana dalam kegiatan pengabdian pada masyarakat sehingga telah berjalan dengan baik, serta kelompok tani Nek'To Noapala Desa Kiuola Kecamatan Noemuti yang telah menerima tim sebagai mitra dalam memajukan produksi peternakan.

\section{DAFTAR PUSTAKA}

Amin, M., Sofyan, D.M., Oscar, Y., Mohammad, I. 2015. Pengaruh Lama Fermentasi Terhadap Kualitas Jerami Padi Amoniasi Yang Ditambah Probiotik Bacillus Sp. Jurnal ilmu dan teknologi peternakan Indonesia, volume 1 (1): 8-13: desember 2015 ISSN: $2460-6669$

Antonius. 2009. Potensi jerami padi hasil fermentasi probion sebagai bahan pakan dalam ransum sapi Simmental. Seminar nasional teknologi peternakan dan veteriner. $240-245$.

Hidayat, N. 2006. Mikrobiologi industri. Penerbit Andi offset. Yogyakarta.

Haryanto, B. 2003. Jerami Padi Fermentasi Sebagai Ransum Dasar Ruminansia. Warta penelitian dan pengembangan pertanian, 25 (3):1-2 
Ilham F., Muhammad Sayuti, Tri Ananda Erwin Nugroho. 2018. Peningkatan Kualitas Jerami Padi Sebagai Pakan Sapi Potong Melalui Amoniasi Mengunakan Urea Di Desa Timbuolo Tengah Provinsi Gorontalo. Jurnal pengabdian kepada masyarakatVolume 24 No. 2, April - Juni 2018 p-ISSN: 0852-2715 | e-ISSN: $2502-7220$

Kaunang, C. L. 2004. Respon Ruminan Terhadap Pemberian Hijauan Pakan yang Dipupuk Air Belerang.Disertasi. Program Pasca Sarjana IPB, Bogor.

Komar, A. 1984. Teknologi Pengolahan Jerami Sebagai Makanan Ternak. Cetakan pertama. Yayasan Dian Grahita Bandung-Indonesia.

Martawidjaja, M. 2003. Pemanfaatan Jerami Padi Sebagai Pengganti Rumput Untuk Ternak Ruminansia Kecil. Wartazoa Vol 13 No. 3 tahun 2003.

Soekartiwi, 1984. Bahan Makanan Ternak Limbah Pertanian Dan Industri. BPFE Yogyakarta

Yanuartono, Purnamaningsih H, Soedarmanto Indarjulianto dan Alfarisa Nururrozi. 2007. “Potensi jerani sebagai pakan ternak”. Jurnal Ilmu-Ilmu Peternakan 27 (1): 40 62 